the presentation of Hodgkin's disease. There are certain points in our report that deserve comment; the first concerns the difficulties in diagnosing extranodal Hodgkin's disease. The presence of RS cells, even when they are $\mathrm{CD} 15+$, is not diagnostic of Hodgkin's disease as $\mathrm{CD} 15$ + RS-like cells have been described in T cell non-Hodgkin's lymphoma. ${ }^{10}$ RS-like cells (CD15-) were present in the bone marrow of a patient with common variable immunodeficiency who developed a peripheral $\mathrm{T}$ cell non-Hodgkin's lymphoma. ${ }^{7}$ In the case reported here, it was the combination of typical histopathology and immunophenotype that was diagnostic of Hodgkin's disease in the bone marrow. The nature of the lymphoproliferative infiltrate found on rectal biopsy was less clear but it should be noted that, although colonic localisation of Hodgkin's disease is considered extremely unusual in previously immunocompetent patients, this might not be the case in immunodeficient subjects.

Although the response of this patient to treatment was gratifying, there were many problems caused by the chemotherapy. The unusual severity of mucositis and gastrointestinal symptoms might be related to compromised mucosal defences because of his severe IgA deficiency. The rapidly advancing viral retinitis-uncommon in most immunocompetent patients undergoing chemotherapy-was compatible with the tendency of latent viruses to reactivate in patients with common variable immunodeficiency. Doubling the dose of $\gamma$ globulin during treatment with foscarnet may have played a role in the spectacular resolution of fundal changes.
In conclusion, this case report of Hodgkin's disease complicating common variable immunodeficiency illustrates that aggressive combination chemotherapy can be successful even in stage IVB disease, although unusual clinicopathological presentations and a broad spectrum of treatment related complications should be anticipated.

We thank Drs G Daikos and N Markomichelakis for help with the clinical management of this patient and Drs M Daemonacou and C Liloglou for performing histopathology studies and PCR analyses, respectively.

1 Cunningham-Rundles C. Clinical and immunologic analyses of 103 patients with common variable immunodeficiency. $f$ Clin Immunol 1989;9:22-33.

2 Spickett GP, Webster ADB, Farrant J. Cellular abnormalities in common variable immunodeficiency. Immunodefic Rev 1990;2:199-219.

3 Hermans PE, Diaz-Buxo JA, Stobo JD. Idiopathic lateonset immunoglobulin deficiency: Clinical observations in 50 patients. $\mathrm{Am} \mathcal{F} \mathrm{Med}$ 1976;61:221-37.

4 Hermaszewski RA, Webster ADB. Primary hypogammaglobulinaemia: A survey of clinical manifestations and complications. $O f$ Med $1993 ; 86: 31-42$.

5 Kinlen LJ, Webster ADB, Bird AG, Haile R, Peto J, Soothill $\mathrm{JF}$, et al. Prospective study of cancer in patients with $J \mathrm{~F}$, et al. Prospective study of cancer in patients

6 Gelmann E, Anderson T, Jaffe E, Broder S. Chemotherapy for lymphoma in a patient with common variable immunodeficiency. Case report, literature review and recommendations for chemotherapy in immunodeficient patients. Arch Intern Med 1982;142:90-2.

$7 \mathrm{Kim}$ JH, Bedrosian CL, Jain R, Schlossman DM. Peripheral T-cell lymphoma complicating common variable hypogammaglobulinaemia. Am $\mathcal{F}$ Med 1988;85:123-5.

$8 \mathrm{Shi}$ SR, Key ME, Kalva KL. Antigen retrieval in formalin fixed paraffin-embedded tissues: an enhancement method for immunohistochemical staining based on microwave oven heating of tissue sections. $\mathcal{F}$ Histochem Cytochem 1991; 39:741-8.

9 Frizzera G, Rosai J, Dehner LP, Spector BD, Kersey $\mathrm{JH}$. Lymphoreticular disorders in primary immunodeficiencies: New findings based on an up-to-date histologic classification of 35 cases. Cancer 1980;46:692-9.

10 Hyder DM, Schnitzer B. Utility of Leu M1 monoclonal antibody in the differential diagnosis of Hodgkin's disease. Arch Pathol Lab Med 1986;110:416-19.

\title{
Immunohistochemical analysis of $\mathrm{T}$ cell proliferation in normal tonsil and B cell lymphoma
}

\author{
J Wang, P G Isaacson, J Spencer
}

Department of
Histopathology,
University College of
London Medical
School,
University Street,
London WC1E 6JJ
J Wang
P G Isaacson
J Spencer
Correspondence to:
Dr J Spencer.
Accepted for publication
21 February 1995

\begin{abstract}
A double immunohistochemical technique, incorporating MIB1 and CD3, was used to identify proliferating $T$ cells in paraffin wax sections of normal tonsil and $B$ cell lymphomas. The number of double stained $T$ cells as a percentage of the total $T$ cells was then determined. In normal tonsil and follicular lymphoma the follicle centre and $T$ cell zones were counted independently. In normal tonsil very few $T$ cells in the follicle centre expressed MIB1. Proliferating $T$ cells were concentrated in the $T$ cell zones. The same pattern was
\end{abstract}

observed in follicular lymphoma. In contrast, the percentage of $T$ cells expressing MIB1 was higher in mucosa associated lymphoid tissue type lymphoma and lymphocytic lymphoma, suggesting that $T$ cell activation occurs in these tumours. The highest percentage of MIB1 positive $T$ cells was observed in high grade lymphoma. This suggests that transformation to high grade lymphoma is associated with an increase in $\mathbf{T}$ cell activation.

(f Clin Pathol 1995;48:873-875)

Keywords: T cell, B cell, lymphoma, proliferation. 
Tumour infiltrating $T$ cells are present in many malignancies including most $B$ cell lymphomas. Most are CD4 positive and many have the characteristic phenotype of chronically activated $T$ cells, suggesting that they have a functional role in the tumour. ${ }^{1}$ Recent evidence suggests that $T$ cells may support the proliferation of malignant $B$ cells in low grade lymphomas. ${ }^{23}$ In low grade primary $B$ cell gastric lymphoma of mucosa associated lymphoid tissue (MALT type lymphoma) tumour cells proliferate in vitro in response to Helicobacter pylori. This proliferative response requires contact dependent help from $H$ pylori specific tumour infiltrating $\mathrm{T}$ cells. ${ }^{4}$ Follicle centre $\mathrm{T}$ cells are predominantly $\mathrm{CD} 4$ positive/ CD45RO positive 5 and show evidence of effector function, in particular the synthesis of interleukin $4 .^{6}$ The follicle centre, however, is not a significant site of $\mathrm{T}$ cell proliferation. ${ }^{7}$ There is evidence that $T$ cells with specificity for antigen accumulate in the follicle centre, suggesting that they are derived from proliferating precursors in a different microanatomical location. ${ }^{8}$ As part of our continued study of the role of T cells in B cell lymphomas, we have quantified $T$ cell proliferation in normal tonsil and a panel of B cell lymphomas, including both low and high grade cases of nodal and extranodal disease, to look for evidence of $\mathrm{T}$ cell proliferation as an indicator of $T$ cell activation, though not necessarily of effector function.

\section{Methods \\ TISSUE}

A panel of paraffin wax embedded tissues was selected which included normal tonsil $(n=5)$, follicular lymphomas (centroblastic/centrocytic; $n=5$, of which two were predominantly small cleaved cell and three were mixed according to the Working Formulation), chronic lymphocytic lymphomas $(n=5)$, mantle cell lymphomas $(n=3)$, low grade MALT type lymphomas $(n=5)$, high grade $B$ cell nodal lymphomas $(n=6)$, and high grade MALT type lymphomas $(n=3)$.

\section{IMMUNOHISTOCHEMISTRY}

Sections $3-5 \mu \mathrm{m}$ thick were cut onto Vector Bond coated slides. Sections were stained immunohistochemically following antigen retrieval using a pressure cooker. Slides in citrate buffer ( $\mathrm{pH} \mathrm{6.0)}$ were maintained at $103 \mathrm{kPa}$ (15 psi) pressure for two minutes. They were then double stained using rabbit anti-CD3 to detect $\mathrm{T}$ cells and MIB1 to detect the $\mathrm{Ki67}$ antigen in proliferating cells. Binding of antiCD3 was detected using an indirect immunoperoxidase technique with swine antirabbit immunoglobulins and diaminobenzidine as chromogen. Reactivity of MIB1 was detected using biotinylated rabbit antimouse immunoglobulins followed by avidin conjugated alkaline phosphatase and fast blue as chromogen. No counterstain was used. All primary and secondary antibodies were purchased from
Table 1 The percentage ( $\pm S E$ ) of $T$ cells expressing MIB1 in normal tonsil and follicular lymphoma. The range is shown in parentheses

\begin{tabular}{lll}
\hline Classification & Intrafollicular & Interfollicular \\
\hline Normal tonsil $(\mathrm{n}=5)$ & $0 \cdot 1 \pm 0 \cdot 1$ & $2 \cdot 6 \pm 0 \cdot 2$ \\
Follicular lymphoma $(\mathrm{n}=5)$ & $(0-0 \cdot 3)$ & $(1 \cdot 9-3 \cdot 2)$ \\
& $0 \cdot 5 \pm 0 \cdot 2$ & $3 \cdot 2 \pm 0 \cdot 2$ \\
& $(0-0 \cdot 9)$ & $(2 \cdot 5-3 \cdot 8)$ \\
\hline
\end{tabular}

Table 2 The percentage $( \pm S E)$ of $T$ cells expressing MIB1 in diffuse infiltrates of tumour cells. The range is shown in parentheses

\begin{tabular}{lc}
\hline Classification & Percentage of $T$ cells \\
\hline Low grade & \\
mantle cell lymphoma $(\mathrm{n}=3)$ & $5 \cdot 1 \pm 0 \cdot 8(3 \cdot 7-6 \cdot 6)$ \\
MALT type lymphoma $(\mathrm{n}=5)$ & $8 \cdot 3 \pm 1 \cdot 7(5 \cdot 0-15)$ \\
lymphocytic lymphoma $(\mathrm{n}=5)$ & $11 \cdot 2 \pm 3 \cdot 0(5 \cdot 8-22 \cdot 6)$ \\
& \\
High grade & \\
MALT type lymphoma $(\mathrm{n}=3)$ & $15 \cdot 6 \pm 0 \cdot 5(14 \cdot 8-16 \cdot 6)$ \\
nodal B cell lymphoma $(\mathrm{n}=6)$ & $32 \cdot 8 \pm 3 \cdot 8(22 \cdot 2-47 \cdot 9)$ \\
\hline
\end{tabular}

Dako, High Wycombe, UK. All other reagents were purchased from Sigma, Poole, Dorset, UK.

ANALYSIS OF TISSUE SECTIONS

Immunohistochemical reactivity was quantified using a SeeScan image analyser. Fields under $\times 400$ were viewed on a monitor and total $T$ cells and the double positive proliferating $T$ cells in a designated area were marked on the monitor and counted. Fifteen fields were counted randomly on each slide. The percentage of $\mathrm{T}$ cells expressing MIB1 was then calculated. In tonsil and follicular lymphomas results for the intra- and interfollicular areas were calculated independently.

\section{Results}

NORMAL TONSIL

In double stained preparations proliferating $T$ cells were visualised as those coexpressing CD3 (brown surface stain) and MIB1 (blue nuclear stain). In normal tonsil the percentage of $T$ cells expressing MIB1 was highest in the interfollicular $\mathrm{T}$ cell zones containing the high endothelial venules (table 1 ). Relatively few $\mathrm{T}$ cells in the follicle centres expressed MIB1 in contrast to the high $\mathrm{B}$ cell proliferation fraction. Therefore, $T$ cell proliferation was not associated with B cell proliferation.

\section{LOW GRADE LYMPHOMA}

The percentage of $T$ cells expressing MIB1 varied between zones of the same lymphoma and varied between lymphoma types. In follicular lymphoma, as in normal tonsil, the percentage of proliferating $T$ cells was highest in the interfollicular area. Little $T$ cell proliferation was observed in the neoplastic follicle centres (table 1). In the other low grade lymphomas studied $\mathrm{T}$ cells were more diffusely distributed throughout the tumour. There was a higher percentage of MIB1 positive $T$ cells in MALT type lymphoma and lymphocytic 
lymphoma, than observed in normal tonsillar $\mathrm{T}$ cell zones or $\mathrm{T}$ cell zones in follicular lymphomas, with no overlap in the ranges (table 2).

\section{HIGH GRADE LYMPHOMA}

The percentage of T cells expressing MIB1 in high grade nodal lymphoma was higher than that observed in normal lymphoid tissue or any low grade lymphoma (table 2). There was no apparent correlation between a high percentage of T cells expressing MIB1 and the expression of MIB1 in the tumour cell population within the group of high grade MALT type and high grade nodal lymphomas.

\section{Discussion}

In this study we have confirmed that $T$ cells in the follicle centres of normal tonsil are not in cell cycle. This is consistent with their role as effector $T$ cells which have been shown to provide contact dependent and cytokine mediated help for B cell proliferation. The site of maximal $\mathrm{T}$ cell proliferation was observed to be the $\mathrm{T}$ cell zone. This is consistent with the distribution of HLA class II rich dendritic cells which process and present peptides to CD4 positive $T$ cells. We have shown that, as in normal follicle centres in the tonsil, the $T$ cells in malignant follicle centres in follicular lymphoma are not in cell cycle. $T$ cell proliferation was concentrated in the areas between the malignant follicles. The $\mathrm{T}$ cells associated with tumour cells in follicular lymphoma probably have a similar role to normal follicle centre $\mathrm{T}$ cells, providing help for tumour cell proliferation. ${ }^{9}$ There is experimental support for this in that $T$ cells have been shown to be able to provide contact dependent help for proliferation of follicular lymphoma cells in vitro. ${ }^{2}$ The relatively low rate of $\mathrm{T}$ cell proliferation observed in malignant follicle centres contrasts with the relatively high rate of $T$ cell proliferation observed in the tumour nodules in lymphocyte predominant Hodgkin's disease. ${ }^{10}$

In low grade MALT type lymphoma and lymphocytic lymphoma the percentage of $\mathrm{T}$ cells expressing MIB1 was higher than the percentage observed in the $T$ cell zone of normal tonsil or in follicular lymphoma. This is consistent with the presence of $\mathrm{T}$ cell activation in the microenvironment of the tumour cells in MALT type lymphoma and lymphocytic lymphoma, but not in follicular lymphoma. In mantle cell lymphoma a higher percentage of $T$ cells expressed MIB1 than was observed in normal tonsil. However, this was not as marked as in MALT type lymphoma and lymphocytic lymphoma. We have shown in earlier studies that proliferation of tumour cells in low grade gastric lymphoma is dependent on help from $H$ pylori specific $\mathrm{T}$ cells. ${ }^{4}$ In the case of MALT type lymphoma, therefore, $T$ cell activation may be in response to $H$ pylori derived peptides.

It is interesting to note that the rate of $T$ cell proliferation was generally higher in high grade lymphoma than in low grade lymphoma. This difference was particularly marked in the nodal lymphomas studied. This is consistent with another study showing that the expression of HLA class II antigens by $T$ cells increases with increasing lymphoma grade. ${ }^{1}$ This suggests that transformation from low to high grade lymphoma is associated with an increase in $\mathrm{T}$ cell activation. The significance of this is not yet known.

1 Diaz JI, Edinger MG, Stoler MH, Tubbs RR. Activated Tcell subsets in benign lymphoid hyperplasias and B-cell non-Hodgkin's lymphomas. Am f Pathol 1991;139:503-9.

2 Umetsu DT, Esserman L, Donlon TA, Dekruyff RH, Levy $R$. Induction of proliferation of human follicular (B type) lymphoma cells by cognate interaction with CD4 $+\mathrm{T}$ cell clones. F Immunol 1990;144:2550-7.

3 Hussell T, Isaacson PG, Crabtree JE, Spencer J. The response of cells from low-grade B-cell gastric lymphomas of mucosa-associated lymphoid tissue to Helicobacter pylori mucosa-associated lymp

4 Hussell T, Isaacson PG, Crabtree JE, Spencer J. Helicobacter pylori specific $T$ cells provide contact dependen help for the growth of malignant B cells in low grade gastric lymphoma of mucosa associated lymphoid tissue. $\underset{\mathcal{F}}{ }$ Pathol 1995; in press.

5 Janossy G, Bofill M, Rowe D, Muir J, Beverley PCL. The tissue distribution of $\mathrm{T}$ lymphocytes expressing differen CD45 polypeptides. Immunology 1989;66:517-25.

6 Butch AW, Chung GH, Hoffmann JW, Nahm MH. Cytokine expression by germinal centre cells. F Immunol 1993;150: 39-47.

7 Berman MA, Rafiei S, Gutman GA. Association of T cells with proliferating cells in lymphoid follicles. Transwith proliferating cells in

8 Fuller KA, Kanagawa O, Nahm MH. T cells within germinal centres are specific for the immunizing antigen. F Immunol 1993:151:4505-12.

9 Clark EA, Ledbetter JA. How B and T cells talk to each other. Nature 1994;367:425-8.

10 Schmid C, Sweeney E, Isaacson PG. Proliferating cell nuclear antigen (PCNA) expression in Hodgkin's disease. $\mathcal{f}$ Pathol 1992;168:1-6. 